\title{
INDONESIA AS NON-PERMANENT MEMBER OF UNITED NATIONS SECURITY COUNCIL, GUARDING THE PEACE AND STABILITY IN ASEAN
}

\author{
Afandi Sitamala \\ Departement of International Law, Universitas Sultan Ageng Tirtayasa, Indonesia, \\ Email: asitamala@untirta.ac.id
}

Submitted: July 30, 2020; Reviewed: August 26, 2020; Accepted: September 16, 2020

\begin{tabular}{ll}
\hline \multicolumn{1}{c}{ Article Info } & \multicolumn{1}{c}{ Abstract } \\
\hline Keywords: & The overall objective underlying the establishment of the UN \\
ASEAN, Role, non- & Security Council was to "save succeeding generations from the \\
Permanent, UNSC & scourge of war" (Preamble to the UN Charter) which used as \\
& the official campaign by the Indonesia Foreign Ministry, \\
DOI: & Indonesia stated itself as 'A True Partner for World Peace'. By \\
10.25041/lajil.v2i2.2037 & that, Indonesia expresses the gravity of its membership by \\
& aiming towards ascertaining collaborations between the \\
& regional organizations in maintaining stability in the regional \\
& area (ASEAN). Indonesia's goals for bridging UNSC \\
& hegemony on the global level and bringing the stability of the \\
& ASEAN area is going to be effortful. The challenge of \\
& establishing the UN resolution as a legal instrument in \\
& municipal law becomes one of the biggest challenges. The two \\
& years of tenure also grow into a barrier toward Indonesian \\
contributions. This study aims to analyze Indonesia role as the & non-permanent member of UNSC globally and in the ASEAN \\
& Region. The final results were presented in a descriptive \\
manner, which gives an overview of how Indonesia's role in \\
the UNSC, and how Indonesia's aimed toward synergized \\
ASEAN.
\end{tabular}

\section{A. Introduction}

The United Nations (UN) remains the only institution where almost all countries, whether friendly or hostile, carry out communication, discussion, and open debate either openly or closely. It can be understood that the main reason for many countries flocking to become members of the UN is as an institution of the largest International Organization, the UN plays an important role in global issues that occur at this time. The UN is also an international symbol of hope for world peace and security through global cooperation, dialogue, and response to threats to security and peace. ${ }^{1}$ One of the bodies in the United Nations is the Security Council. The Security Council is the main body of the United Nations consisting of the United States, Britain, France, the Soviet Union and China as permanent members of the Security Council.

\footnotetext{
${ }^{1}$ Jean E. Krasno, Founding the United Nations: An Evolutionary Process, A Book Chapter in Jean E. Krasno (ed), The United Nations: Confronting the Challenges of a Global Society (London: Lynne Rienner, 2004), 19.
} 
The Security Council has a special task in the field of international peace and security where these five countries have a role in the fight against fascism. ${ }^{2}$

On June 8, 2018, Indonesia was elected a Non-Permanent Member of the UN Security Council (UNSC) from 2019 to 2020, along with Germany, South Africa, Belgium, and the Dominican Republic. Indonesia will start its term of office on January 1, 2019, until December $31,2020{ }^{3}$ The membership of the Indonesian UNSC is the fourth time after previously Indonesia became a non-permanent member of the UNSC in 1974-1975, 1995-1996, and 20072008.

On the fourth time of its membership, Indonesia carries four priority issues and one issue of special attention, namely: First, to continue the contribution of the Government of Indonesia in its efforts to realize world peace, Second Build synergies between regional organizations, Third increase cooperation between countries and the UNSC to combating terrorism, extremism and radicalism, the Fourth synergize efforts to create peace with sustainable development efforts. As for the issue of special attention is regarding Palestine. ${ }^{4}$ The election of Indonesia as a non-permanent member of the UNSC has placed Indonesia in the epicentre of decision making at the global level. ${ }^{5}$ One of the challenges faced by Indonesia in its two-year tenure of membership is to become a regional power that can be a link between the region and the agenda of the UNSC.

Some of the researcher's views on the UNSC and the region (Max Planck: 2000) see sooner or later the credibility of the UNSC can collapse if there is no "underrepresented" representation of the voices of countries outside the permanent members of the UNSC. ${ }^{6}$ (David Freestone: 2002) explained that the International Legal Action in the framework of protection against the threat of transnational terrorism requires cooperation from every country (Area). ${ }^{7}$ Meanwhile, (Erika de Wet: 2004), explained that the understanding of the areas/regions in Chapter VIII of the UN Charter must be separated from defence organizations, whose main purpose is to offer protection against military aggression. The defence is regulated explicitly by article 51 of the UN Charter. ${ }^{8}$

\footnotetext{
${ }^{2}$ Desia Rakhma Banjarani et al., "PERLINDUNGAN TERHADAP WARTAWAN PERANG DI DAERAH KONFLIK BERSENJATA MENURUT HUKUM INTERNASIONAL (STUDI KASUS DAERAH KONFLIK IRAK DAN SURIAH) PROTECTION OF WAR REPORTERS IN ARMED CONFLICT AREAS BASED ON INTERNATIONAL LAW (CASE STUDY OF THE IRAQ AND SYRIA CONFLICT)," Cepalo 3, no. 1 (2019): 11-18, 16, DOI: $10.25041 /$ cepalo.v3no1.1789.

${ }^{3}$ https://kemlu.go.id/portal/id/page/42/keanggotaan_indonesia_pada_dk_pbb, Accessed on July 8, 2019, 23. 30.

${ }^{4}$ Indonesia Campaign Pamphlet by the Ministry of Foreign Affairs Indonesia, 'Indonesia A True Partner for World Peace' $2^{\text {nd }}$ Edition, March 2017

${ }^{5}$ Ricky Suhendar Director of Law and Treaty the Ministry of Foreign Affairs Indonesia stated "the status of Indonesia as a non-permanent member of the United Nations Security Council had placed Indonesia in the epicenter of decision making at the global level..." as can be seen on https://en.antaranews.com/news/122080/indonesia-should-establish-legal-instrument-for-unsc-resolution, Accessed on July 82019.

${ }^{6}$ Princeton N. Lyman, "SAVING THE UN SECURITY COUNCIL-A CHALLENGE FOR THE UNITED STATES", Max Planck Yearbook of United Nations Law Online 4, no. 1 (2000): 127-146, 136, DOI: $10.1163 / 187574100 x 00052$... "It is seen as decidedly unrepresentative. Its membership has only expanded...There are other power centers today not so represented..."

${ }^{7}$ David Freestone, The Principle of Co-Operation: Terrorism a book chapter in The United Nations and the Principles of International Law (London: Routledge, 2002), 137... "International legal action to meet the threat of transnational terrorism requires the co-operation of States. That co-operation cannot be assumed and has not always been forthcoming..."

${ }^{8}$ Erika de Wet, The Chapter VII Powers of The United Nations Security Council (Portland, Oregon: Hart Publishing, 2004), 292. "Regional organisations are thereby distinguished from a regional defence organisation, which has as its sole purpose the offering of protection against external aggression. Whereas regional organisations are governed by Chapter VIII of the Charter, defence organisations are governed by Article 51 of the Charter."
} 
The structure of the articles is divided between section with abstract as the miniseries of the articles. The introduction presents some terminology used in the UN, Indonesian background in the UN, in addition to the structure and research method that is used to analyze the two main issues. In the discussion section, the writer brought up two main issues which are the role of Indonesia in UNSC and the ASEAN region. This study aims to analyze Indonesia role as the non-permanent member of UNSC globally and in the ASEAN Region. What are Indonesia's challenges in becoming a regional nexus; What is Indonesia took the feasible actions in a twoyear tenure; What is Indonesia's strategy in building synergize ASEAN and UNSC. The method used to present this article is using normative legal research methods by illustrating how Indonesia's role in the UNSC. This research does not try to explain the reform of the UNSC institution, nor does it try to answer the hegemony or veto system of the UNSC P-5. More comprehensive research is needed to describe the reform agenda of the UNSC with its five permanent members.

\section{B. Discussion}

\section{Indonesia Feasible Action as non-Permanent Member of UNSC}

Provisions regarding the composition of the UNSC membership are regulated in Chapter V, Article 23 of the UN charter. Earlier in 1965, the membership of the UNSC was eleven members ${ }^{9}$. Article 23 After being amended, the total number of members of the UNSC becomes 15 countries consisting of 5 permanent members and ten non-permanent members. They have a term of office of two years. ${ }^{10}$ Non-permanent members of the UNSC other than a term of office of only two years, two other criteria must be fulfilled namely: a.) The candidate country has at least made a contribution to the United Nations in maintaining peace and security, and b.) geographical balance. ${ }^{11}$ The UNSC is one of the six main UN organs, with the main mandate to maintain international peace and security. The UN Charter stipulates that: the UNSC can act on behalf of all other UN member states (article 24), ${ }^{12}$ and all members of the UN agree to accept and carry out the decisions of the UNSC (article 25). ${ }^{13}$ This is the main difference between the UNSC and the General Assembly (UNGA). UNGA resolution is non-binding though it is decided by all member states, while the UNSC decision is binding even if it is determined only by several countries.

The UNSC consists of 15 member countries, namely five permanent members (US, UK, France, PRC, Russia) and ten non-permanent members. Each non-permanent member has a 2year membership period (Indonesian membership period started from January 1, 2019, to

\footnotetext{
${ }^{9}$ Marthinus Omba, "TANGGUNGJAWAB DAN PERANAN DEWAN KEAMANAN PERSERIKATAN BANGSA-BANGSA DALAM MEMELIHARA PERDAMAIAN DAN KEAMANAN INTERNASIONAL", Jurnal Hukum Internasional 5, no. 4, (2008): 766-788, 770, DOI: http://dx.doi.org/10.17304/ijil.vol5.4.187.

${ }^{10}$ Madeleine O. Hosli, "SQUARING THE CIRCLE? SECURITY COUNCIL REFORM", Rev Int Organ 6, (2011): 163-187, 165, DOI 10.1007/s11558-011-9101-1.

${ }^{11}$ Yukari Iwanami, "REGIONAL CAUCUS GROUPINGS AND THE NOMINATION PROCESS FOR NONPERMANENT MEMBERS”, Social Science Research Network Electronic Journal, April edition, (2018), DOI: $10.2139 /$ ssrn.3169142.

${ }^{12}$ UN Charter Article $24(1 ; 2 ; 3 ; 4)$ In order to ensure prompt and effective action by the United Nations, its Members confer on the Security Council primary responsibility for the maintenance of international peace and security, and agree that in carrying out its duties under this responsibility the Security Council acts on their behalf. 2. In discharging these duties the Security Council shall act in accordance with the Purposes and Principles of the United Nations. The specific powers granted to the Security Council for the discharge of these duties are laid down in Chapters VI, VII, VIII, and XII. 3. The Security Council shall submit annual and, when necessary, special reports to the General Assembly for its consideration

${ }^{13}$ UN Charter Article 25 The Members of the United Nations agree to accept and carry out the decisions of the Security Council in accordance with the present Charter.
} 
December 31 2020). At the time Indonesia began its membership, the composition of 14 other UNSC member countries was:

\begin{tabular}{|l|l|l|l|}
\hline \multicolumn{1}{|c|}{ Negara } & \multicolumn{1}{c|}{$\begin{array}{c}\text { Status } \\
\text { Keanggotaan }\end{array}$} & \multicolumn{1}{c|}{ Negara } & Status Keanggotaan \\
\hline Amerika Serikat & Tetap & Kuwait & $2018-2019$ \\
\hline Inggris & Tetap & Peru & $2018-2019$ \\
\hline Perancis & Tetap & Polandia & $2018-2019$ \\
\hline Rusia & Tetap & Afrika Selatan & $2019-2020$ \\
\hline China & Tetap & Belgia & $2019-2020$ \\
\hline Côte d'Ivoire & $2018-2019$ & Dominika (Republik) & $2019-2020$ \\
\hline Equatorial Guinea & $2018-2019$ & Jerman & $2019-2020$ \\
\hline
\end{tabular}

(Table 1) Member States of the UNSC source page https://kemlu.go.id/portal

Decision making of the UNSC is carried out by voting, a decision on procedural votes is approved if supported by at least nine member countries regardless of the permanent members or not. Decisions on all other matters are endorsed if supported by at least nine member countries, including all non-permanent UN Member States (veto). A good track record has been achieved by Indonesia while active in UN missions. Indonesia plays an active role in several UN Peace Keeping missions which are real contributions, especially in the realm of the UNSC whose main objectives are world security and peace. In the third period 2007-2008, Indonesia played an important role as a moderating voice, and as a bridge and consensus builder ${ }^{14}$ among other UNSC members. Indonesia has also played an active role as a contributor to UN Peacekeeping Operations (UNPKO) since 1957, more than 30 UNPKOs with the deployment of approximately 30,000 Indonesian troops and police personnel were deployed on a mission to maintain security and peace. ${ }^{15}$

Indonesia's second priority is to build synergy between regional/regional organizations. Where dynamic developments occur in many regions, regional organizations are now considered quick in responding to the issues that occurred in the area. ${ }^{16}$ Both supportive and sceptical views on Indonesia's non-permanent membership in the UNSC are also mutually interlocking. ${ }^{17}$ Many parties are sure and trust the track record of Indonesia which has become the fourth permanent member of the UNSC. ${ }^{18}$ On another note, the Ministry of Foreign Affairs Retno Marsudi state that there are at least four focus areas in Indonesia two-year tenure, namely peacekeeping, conflict prevention, sustainable development and counterterrorism. ${ }^{19}$ Starting from that, what might be done by Indonesia in a period of two years. One definite contribution as a non-permanent member of the UNSC is to initiate the formation of ad hoc alliances on several important regional issues. Non-permanent members of the UNSC can also be interpreted as the potential delivery of the aspirations of developing countries that continue to

\footnotetext{
${ }^{14}$ Kementerian Luar Negeri Indonesia, Indonesia A True Partner for World Peace' $2^{\text {nd }}$ Edition (Jakarta: Kementerian Luar Negeri Indonesia, 2017), 3

${ }^{15}$ Ibid., 6

16 https://en.antaranews.com/news/122080/indonesia-should-establish-legal-instrumentfor-unsc-resolution, accessed on July 18, 2019.

${ }^{17} \mathrm{https} / / /$ theaseanpost.com/srticle/whatwould-indonesia-bring-un-securitycouncil, Accessed on July 18, 2019.

${ }^{18} \mathrm{https}$ ///www.lowyinstitute.org/the-interpreter/when-indonesia-sits-security-council, Accessed on July 18, 2019.

'There is still room for movement, however, and there will be pressure for Indonesia to fulfil the expectations of those who elected them on the basis of its "partner for peace" campaign'

${ }^{19} \mathrm{https}$ ///theaseanpost.com/article/what-would-indonesia-bring-un-security-council, Accessed on July 30, 2020.
} 
grow. ${ }^{20}$ The real contribution of Indonesia as a non-permanent member of the UNSC lies in the use of soft power by continuing to become the exemplars of peacekeeping which is currently ranked $9^{\text {th }}$ out of 121 contributing countries to UNPKO. Indonesia must build cooperation between the non-permanent members of the UNSC in building consensus on global issues and regional issues that also concern Indonesia's interests.

\section{Indonesia as non-Permanent Member of UNSC in the ASEAN Region}

The role of regional organizations varies considerably depending on the characteristics of the regional organization. Like where is the location, how is the organizational structure and leadership. For this reason, if the regional organization has been guided and the structure is clear enough, it will be very beneficial for the sustainability of the organization. ${ }^{21}$ As a subject of international law, the UN can have legal relations between one organization and another. ${ }^{22}$ Also, do agreements between one and the other. With the proliferation of regional organizations, it has created its own decentralized system of legal relations between the UN and regional organizations. Therefore, the UN has special relations with specialized agencies that are within the UN's own organizational structure. ${ }^{23}$

However, while regional organizations have links to important issues of broad power in maintaining regional peace and security, there is a sub-ordination between the UNSC and regional organizations. ${ }^{24}$ This role can be an opportunity for Indonesia as a non-permanent member of the UNSC and initiator in the region. According to the author's view, Indonesia's great opportunity to become a unified voice expresses the aspirations of the region with the $\mathrm{UNSC}^{25}$ in the humanitarian crisis sectors. Especially in the Rohingya humanitarian crisis, the fulfilment of the rights of migrant workers, and the humanitarian approach in dealing with the victims of human trafficking in the region. For some regional issues that require special attention from the UNSC, such as the humanitarian crisis in Myanmar's Rakhine State, many of the regional countries expect Indonesia to bring related issues to the global stage. Until this research was conducted, although the repatriation process of Rohingya residents continued well, Rohingya refugees still did not have citizenship. They were very prone to become victims of violent conflict. ${ }^{26}$

Since the Rohingya humanitarian crisis occurred, the UN Security Council has remained silent on the Rohingya humanitarian issue. Indonesia, as a non-permanent member of the UNSC,

\footnotetext{
${ }^{20}$ Nia Norlyanti, "Indonesia as Non-Permanent Member of United Nations Security Council Pursuit of Peace for Rohingya and Palestine", Atlantis Press 241, 5th International Conference on Social and Political Sciences (ICOSAPS 2018): 102. The Non-Permanent Members in UNSC of course has a contribution to the world. Even the permanent members have a veto to determine the role of UN toward several issue, but for developing states this chance is a major improvement to be heard in international forum.

${ }^{21}$ J.G. Merrills, International Dispute Settlement, $4^{\text {th }}$ Edition (UK: Cambridge University Press, 2005), 280

${ }^{22}$ Ian Brownlie, Principles of Public International Law, $4^{\text {th }}$ Edition (Clarendon Press, Oxford, 1990), 696

${ }^{23} \mathrm{Ibid}$, the International Labour Organizations, the Food and Agricultural Organizations, International Civil Aviation Organizations, World Health Organizations etc.

${ }^{24}$ UN Charter Article 53 (1), "The Security Council shall, where appropriate, utilize such regional arrangements or agencies for enforcement action under its authority. But no enforcement action shall be taken under regional arrangements or by regional agencies without the authorization of the Security Council, with the exception of measures against any enemy state, as defined in paragraph 2 of this Article, provided for pursuant to Article 107 or in regional arrangements directed against renewal of aggressive policy on the part of any such state, until such time as the Organization may, on request of the Governments concerned, be charged with the responsibility for preventing further aggression by such a state. 2 . The term enemy state as used in paragraph 1 of this Article applies to any state which during the Second World War has been an enemy of any signatory of the present Charter".

${ }^{25}$ Regulation regarding the Regional Arrangements as mentioned on chapter VIII of UN Charter, Article 54 stated that "The Security Council shall at all times be kept fully informed of activities undertaken or in contemplation under regional arrangements or by regional agencies for the maintenance of international peace and security."

${ }^{26}$ Anbar Jayadi, With a seat on the UN Security Council, what can key ASEAN member Indonesia do to solve the Rohingya crisis?, The Conversation, 24 September 2018
} 
plays a key role in initiating consensus dialogue at the UNSC forum. As a "natural leader" in the ASEAN region, Indonesia can push the Rohingya refugee crisis into the agenda of the UNSC. At the regional level, Indonesia plays an active role in ensuring the repatriation process runs well. Indonesia also carries out its function as a natural leader in the region by participating in encouraging the implementation of the Kofi Annan report's recommendations. ${ }^{27}$

Rohingya refugees still do not have citizenship to be a problem that until now has not been resolved. Indonesia can initiate the formation of ad hoc alliances at the ASEAN regional level and then begin to call for the attention of the UNSC to build consensus at the global level. With Indonesia's current bargaining position, it is the right time to bring international attention to the stateless issue of Rohingya refugees while continuing to synergize between regional organizations and the UNSC. ${ }^{28}$ The second focus that Indonesia can draw between UNSC and regional organizations is on the fulfilment of migrant workers' rights, especially in Southeast Asia. Migrant workers' rights have been an area issue that has not received international attention lately. The Philippines is a major supporter of regional reforms in the field of migrant workers.

Finally, the author sees that it will be difficult for Indonesia to use its mandate as a nonpermanent member of the UNSC to call attention to the UNSC on the issue of the South China Sea (SCS). Indonesia can contribute as a proponent for regional stability, security, and peace in the region. Although the two-year tenure is a major obstacle for Indonesia to participate fully, Indonesia must still play an active role in bridging the region and the UNSC. With these contributions, Indonesia can become a role model where a country carries its influence through international institutions.

Indonesia's position as a non-permanent member of the UNSC provides a vital opportunity to bring an international focus on related issues and advance synergies at the international level and regional organizations. However, we should also not lose sight of the role of regional organizations in the promotion of preventive diplomacy, peacekeeping, peacemaking and postconflict peacebuilding. While the Security Council would continue to have primary responsibility for maintaining international peace and security, regional organizations should not only provide support to the UNSC but also contribute to a deeper sense of a more democratic international order. ${ }^{29}$

\section{Conclusion}

In two years, the tenure of Indonesia membership, several feasible actions need to be done on a global level is to act as the potential delivery of the aspirations of developing countries that continue to grow. The real contribution of Indonesia as a non-permanent member of the UNSC lies in the use of soft power by continuing to become the exemplars of peacekeeping. Indonesia can act as an initiator in the region. Regional organizations have links to important issues of broad power in maintaining regional peace and security. There is a sub-ordination between the UNSC and regional organizations.

To sum up, Indonesia's position as a non-permanent member of the UNSC provides a vital opportunity to bring an international focus on related issues and advance synergies at the international level and regional organizations. Indonesia must also understand that it not only

\footnotetext{
27 The Jakarta Post, Indonesia: Partner for Peace, security, prosperity, Januari 11, 2018

${ }^{28}$ Further reads Sian Troath on Iowyinstitute.org stated that "Indonesia's position as a non-permanent member of the Security Council will provide a vital chance to focus international attention on the issue and work towards advancing synergy between international and regional organizations.",

29 https://www.thejakartapost.com/academia/2018/06/11/great-opportunity-great-responsibility.html, Accessed July 30, 2020.
} 
represents Southeast Asia per se but also the wider Asia Pacific and cannot pursue its interests while on the council. ${ }^{30}$

\section{A. Journal}

\section{References}

Banjarani, Desia Rakhma et al., "PERLINDUNGAN TERHADAP WARTAWAN PERANG DI DAERAH KONFLIK BERSENJATA MENURUT HUKUM INTERNASIONAL (STUDI KASUS DAERAH KONFLIK IRAK DAN SURIAH) PROTECTION OF WAR REPORTERS IN ARMED CONFLICT AREAS BASED ON INTERNATIONAL LAW (CASE STUDY OF THE IRAQ AND SYRIA CONFLICT)," Cepalo 3, no. 1, 2019: 1118, DOI: 10.25041/cepalo.v3no1.1789.

Iwanami, Yukari. "REGIONAL CAUCUS GROUPINGS AND THE NOMINATION PROCESS FOR NON-PERMANENT MEMBERS”, Social Science Research Network Electronic Journal, April edition, 2018, DOI: 10.2139/ssrn.3169142.

Lyman, Princeton N. Lyman. "SAVING THE UN SECURITY COUNCIL-A CHALLENGE FOR THE UNITED STATES", Max Planck Yearbook of United Nations Law Online 4, no. 1, 2000: 127-146, DOI: 10.1163/187574100x00052.

Madeleine O. Hosli, "SQUARING THE CIRCLE? SECURITY COUNCIL REFORM", Rev Int Organ 6, 2011: 163-187, 163, DOI 10.1007/s11558-011-9101-1

Norlyanti, Nia. "INDONESIA AS NON-PERMANENT MEMBER OF UNITED NATIONS SECURITY COUNCIL PURSUIT OF PEACE FOR ROHINGYA AND PALESTINE", Atlantis Press 241, 5th International Conference on Social and Political Sciences (ICOSAPS 2018): 102.

Omba, Marthinus. "TANGGUNGJAWAB DAN PERANAN DEWAN KEAMANAN PERSERIKATAN BANGSA-BANGSA DALAM MEMELIHARA PERDAMAIAN DAN KEAMANAN INTERNASIONAL”. Jurnal Hukum Internasional 5, no. 4, 2008: 766-788, DOI: 10.17304/ijil.vol5.4.187.

\section{B. Book}

Brownlie, Ian. Principles of Public International Law, $4^{\text {th }}$ Edition. Oxford: Clarendon Press, 1990.

E, Jean. Founding the United Nations: An Evolutionary Process, a book chapter in Jean E. Krasno (ed), The United Nations: Confronting the Challenges of a Global Society. London: Lynne Rienner, 2004.

Freestone, David. The Principle of Cooperation: Terrorism, a book chapter in The United Nations and the Principles of International Law. London: Routledge, 2002.

Kementerian Luar Negeri Indonesia. Indonesia A True Partner for World Peace' $2^{\text {nd }}$ Edition. Jakarta: Kementerian Luar Negeri Indonesia, 2017.

Merrills, J. G. International Dispute Settlement, $4^{\text {th }}$ Edition. UK: Cambridge University Press, 2005.

Wet, Erika de. The Chapter VII Powers of The United Nations Security Council. Portland, Oregon: Hart Publishing, 2004.

\section{Regulation}

United Nations Charter 1945

${ }^{30}$ Ibid. 


\section{Internet}

https://en.antaranews.com/news/122080/indonesia-should-establish-legal-instrumentfor-unscresolution, January 31, 2019.

https://en.antaranews.com/news/122080/indonesia-should-establish-legal-instrument-forunsc-resolution, Accessed on July 8, 2019.

https://kemlu.go.id/portal/id/page/42/keanggotaan_indonesia_pada_dk_pbb, July 8, 2019, at 23.30 .

https://kemlu.go.id/portal/id/page/46/keanggotaan_indonesia_pada_dk_pbb, Accessed on July 19, 2019.

https://theaseanpost.com/srticle/whatwould-indonesia-bring-un-securitycouncil, Accessed on July 18, 2019.

https://theconversation.com/with-a-seat-on-the-un-security-council-what-can-key-aseanmember-indonesia-do-to-solve-the-rohingya-crisis-102915, Accessed on July 8, 2019.

https://www.lowyinstitute.org/the-interpreter/when-indonesia-sits-security-council, Accessed on July 18, 2019.

The Jakarta Post, Indonesia: Partner for Peace, security, prosperity, January 11, 2018. 